ENTREPRENEURSHIP AND SUSTAINABILITY ISSUES

ISSN 2345-0282 (online) http://jssidoi.org/jesi/

2020 Volume 8 Number 2 (December)

http://doi.org/10.9770/jesi.2020.8.2(24)
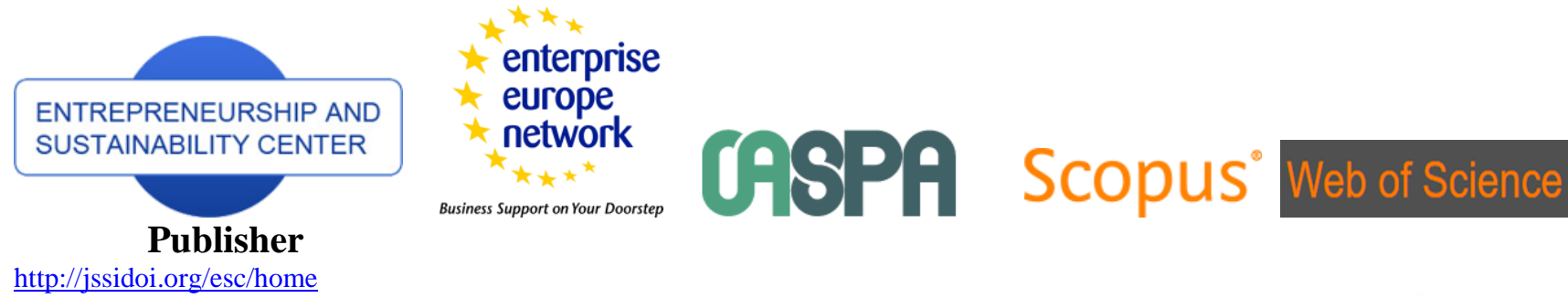

http://jssidoi.org/esc/home

Business Support on Your Doorstep

I Clarivate

Analytics

\title{
ATTITUDES TOWARDS ARTIFICIAL INTELLIGENCE IN THE AREA OF PERSONAL FINANCIAL PLANNING: A CASE STUDY OF SELECTED COUNTRIES *
}

\author{
Krzysztof Waliszewski ${ }^{1}$, Anna Warchlewska ${ }^{2}$ \\ 1,2 Poznań University of Economic and Business, al. Niepodległości 10, 61-875 Poznań, Poland \\ E-mails: ${ }^{1}$ krzysz.tof.waliszewski@ue.poznan.pl; ${ }^{2}$ anna.warchlewska@ue.poznan.pl
}

Received 15 May 2020; accepted 20 August 2020; published 30 December 2020

\begin{abstract}
The financial sector's focus on simplifying decision-making processes, maximally shortening procedures via cooperation with the fintech industry, robotisation and the use of artificial intelligence are a response to market needs and becoming an important element of how financial service groups compete on the market. The theory of consumer behaviour assumes that consumers have needs that they will hierarchise, and that they will make choices to maximise their own satisfaction. The purpose of the article is to diagnose the sociological and economic determinants underlying consumer satisfaction in terms of planning personal finances using modern technologies. Comparisons of international data were conducted via quantitative analysis of robo-advice using Mann-Whitney U tests, the Chi-square test and Spearman's rho correlation. The survey results show that the majority of socioeconomic characteristics of households are statistically significant when considering satisfaction with robo-advisory financial services and spending analysis, as well as with artificial intelligence suggesting improvements. This study is a contribution to the literature on consumer behaviour in the modern world.
\end{abstract}

Keywords: modern financial technologies; personal finance management; robo-advice; personal financial planning

Reference to this paper should be made as follows: Waliszewski, K., Warchlewska, A. 2020. Attitudes towards artificial intelligence in the area of personal financial planning: a case study of selected countries. Entrepreneurship and Sustainability Issues, 8(2), 399-420. http://doi.org/10.9770/jesi.2020.8.2(24)

JEL classification: D12, G41, G53, O33

\section{Introduction}

The effectiveness of using artificial intelligence (Belanche et al. 2018) in various aspects of the economy has been a topic of discussion for many years now. The speed with which users implement and adapt new technological solutions depends on the level of sophistication offered by financial services in a given country. Each financial institution struggles with data overload and the problem of processing and selecting the most relevant. Thanks to technology, robotisation and artificial intelligence, it becomes possible to personalise customer service and switch to remote service channels.

\footnotetext{
* The project was financed within the Regional Initiative for Excellence programme of the Minister of Science and Higher Education of Poland, years 2019-2022, grant no. 004/RID/2018/19, financing 3,000,000 PLN.
} 


\section{ENTREPRENEURSHIP AND SUSTAINABILITY ISSUES}

ISSN 2345-0282 (online) http://jssidoi.org/jesi/

2020 Volume 8 Number 2 (December)

http://doi.org/10.9770/jesi.2020.8.2(24)

Make your research more visible, join the Twitter account of ENTREPRENEURSHIP AND SUSTAINABILITY ISSUES: @Entrepr69728810

The application of modern financial solutions not only serves to minimise the costs associated with employment, but also to target action on the complex problems faced by customers. Robotics and artificial intelligence (Xie, 2019) both significantly influence the financial industry, as the technology used there is a key element in the strategy of banks and emerging financial entities (Baker \& Dellaert 2017; Jung et al. 2018). Replacing traditional consultancy services with innovations, especially at the beginning, is not met with much enthusiasm, mainly due to the novelty factor, competition, fear and lack of knowledge (Belanche at al. 2018).

The global landscape of innovation is undergoing comprehensive transformation due to the growing importance of intangible investment. The fintech concept (Schueffel 2016; Gai et al. 2018; Das \& Ali 2020) currently transcends electronic banking and consumer digitisation services and focuses on the development and implementation of innovative financial instruments to meet the financial requirements of the end-users. Digital technologies (Skinner 2018; Jagtiani \& Kose 2018; Tanda \& Schena 2019) and their impact on consumer decisions currently stand at the forefront of international consumer policy discourse (Zopounidis et al. 2018; Bhatia, 2019). The use of modern technologies presents a clear opportunity to accelerate the transformation of the banking sector and give users greater control over their finances and increase the value of their investments. Asset management support technologies may play a new and promising role in supporting financial decisions that involve analysing decisions in circumstances of uncertainty and a huge diversity of possible decisions. The impact of modern financial technologies on data transfer and security, consumer privacy, as well as the responsibility of financial service providers on online platforms and digital consumer education are just some of the hot topics of our times (Świecka et al. 2020; Thorun \& Diels 2020).

One form of automated financial consulting is robo-advice - defined as an automated investment platform that uses quantitative algorithms to manage investors' portfolios and accessible to clients online. Robo-advisors differ from existing online investment platforms or online brokerage with respect to two different conceptual levels: customer assessment, and customer portfolio management (Beketov et al. 2018; Jung et al. 2018). The solution is based on advanced algorithms using artificial intelligence and tools for analysing large data sets. The robo-advisor (online software) provides vital financial advice to their clients in a cost-effective manner with moderate to minimal human interventions (Balwani et al. 2019). Emergence of financial technologies ecosystem was preceded by three waves of technological disruptive changes: electronic payments, blockchain and cryptocurrencies, and artificial intelligence. The concept of artificial intelligence in the financial sector centers on devices that can interpret and understand tasks and take action to complete those financial tasks. For example, the devices might be robo-advice, digital brokers, or assorted devices used in trading, tax management, and trade decision making. Artificial intelligence offers a high degree of automation and efficiency improvements, which are most apparent in investment platforms and portfolio management (Palmiéa et al., 2020).

Robo-advisors have emerged from the entwinement of two strands of history represented by investment theory and AI-technology during the latter part of the 20th century. The leading robo-advisory models founded in today's AI-driven technological environment are mostly based on Modern Portfolio theory (MPT), based on an optimal portfolio for a given investor's risk preference. Therefore, behavioural finance is considered as one of the most realistic representation of financial markets and investor behaviour, which might eventually replace MPT as the paradigm of choice. This shift to behavioural finance received a further boost in 2017, with recent developments in AI-based machine learning, which have built the momentum through the possible combination of two investment philosophies (Shanmuganathan 2020).

Research into the implementation of robo-advisory solutions in practice is limited (D'Acunto et al., 2019). Literature and reports predominantly focus on technical, legal and market forecasting issues (Jl, 2017; Mordor Intelligence 2017; Netscribes 2018; Glaser et al. 2019; EIBIS 2020), excluding the use of robo-advice in personal 


\section{ENTREPRENEURSHIP AND SUSTAINABILITY ISSUES}

ISSN 2345-0282 (online) http://jssidoi.org/jesi/

2020 Volume 8 Number 2 (December)

http://doi.org/10.9770/jesi.2020.8.2(24)

Make your research more visible, join the Twitter account of ENTREPRENEURSHIP AND SUSTAINABILITY ISSUES: @Entrepr69728810

finance planning. The use of robo-advice has come under the microscope in the USA and China. Over one million Bank of America customers use the services of a chatbot (named Erica) to submit basic financial inquiries (Rosman, 2018). Another example of the practical use of modern technologies is the Bank of Tokyo (Marinova et al., 2017), where a banker-humanoid (named Nao) accompanies the client during a standard visit to the bank. Banks and entities from the fintech industry seek to popularise robo-advice services, claiming that they offer a competitive advantage. It is worth emphasising that the size of the market is expanding, and robo-advisers manage approximately USD 880,000 million of assets and have noted an annual increase of 30\% (Statista.com 2019). Analyses conducted thus far (Lundahl et all 2009; Sabri 2011; Bhatnagar 2016; Iriobe \& Oyinlola 2017) do not relate directly to an assessment regarding which socio-demographic traits - from a statistical point of view - may influence the level of satisfaction experienced by customers (Kim \& Lim 2010) with the use of modern technologies in personal finance in terms of robo-advice and the monitoring of spending habits.

Progress in information technology (IT) and information systems (IS) provides firms with more options for replacing or supplementing personal service provision with self-service technologies (SST). Many of these technologies provide decision support to consumers either as their main purpose (apps, information terminals) or as a fringe benefit (self- scanning) (Djelassia et al., 2018). Robo-advice is an example of customer self-service technology (SST). SST is applicable, among others, in retail and financial services as a customer-centric strategy and fosters loyalty, trust, or word-of-mouth communication (Taillon \& Huhmann 2017). One of the prominent benefits noted by customers is that self-service allows customers to have greater efficiency in a transaction and so they forego the full service option and purchase online (Collier \& Barnes 2015).

The subject of Technology readiness (TR) of SSTs is also discussed in the literature, i.e. the customer's psychological willingness to accept new technologies. TR comprises four dimensions: innovativeness, optimism, discomfort and insecurity. Service providers introduce self-service technologies to increase productivity and efficiency and to offer customers access to services via new and convenient channels, thereby better meeting customer demands and boosting their satisfaction. The impact of TR on customers can be investigated by (1) attitude towards using SSTs, (2) adoption of SSTs, i.e. actual usage and (3) response to the firm in terms of perceived service quality, satisfaction and loyalty to an SST (Liljandera, Gillberg, Gummerus, Rie 2006). Other dimensions of TR are innovativeness and optimism and they have a positive impact on the customers' decisions to use self-service technologies while discomfort and insecurity have a negative impact (Gelderman et al. 2011). SST service quality can be measured by examining many dimensions including functionality, enjoyment, security, assurance, design, customisation and convenience. The quality of self-service technology in retail banking services consists of four elements - consistency, dependability, timeliness and technology - based on two popular dimensions, which are reliability and responsiveness and their influence on customer satisfaction (Iberahim, et al. 2016). The literature also discusses the positive relationship between a self-service technology investment and solid financial performance (Hung et al. 2012). Buyers' continued usage of SSTs depends on their acceptance of the technology and their satisfaction with service delivery based on two different lines of research: technology acceptance and service/relationship marketing. Buyers who are satisfied tend to continue their usage, whereas dissatisfied buyers withdraw (Erikkson \& Nilson 2007). There are no studies on socio-economic factors affecting the satisfaction of using self-service services based on the example of robo-advice. This indicates the existence of a research gap, which the results of the study and their analysis presented in the article intend to fill.

One of the main theories related to the customer self-service process is that of resource matching (Anand \& Sternthal 1999) and its further theoretical development within the field of efficiency (Collier \& Kimes 2012; Zhu et al. 2007). This theory is a reference point for environments where performance is the key goal. Unfortunately, it cannot be fully applied to analyses regarding remote consumer service channels in the financial sector, as it is not 


\section{ENTREPRENEURSHIP AND SUSTAINABILITY ISSUES}

ISSN 2345-0282 (online) http://jssidoi.org/jesi/

2020 Volume 8 Number 2 (December)

http://doi.org/10.9770/jesi.2020.8.2(24)

Make your research more visible, join the Twitter account of ENTREPRENEURSHIP AND SUSTAINABILITY ISSUES: @Entrepr69728810

appropriate for the dynamics of action and operations performed independently. The theory of consumption values focuses on efficiency (which better describes consumer behaviour in the digital financial services market), explaining why consumers decide to buy (Sheth et al. 1991). Financial service providers using remote applications strive towards increased efficiency, performance and diversification of communication channels (Liljander et al. 2006; Collier \& Barnes 2015; Iberahim et al. 2015). Customer self-services enables a new service model to be created that bases its assumptions on the equal involvement of investors and bidders in the financial management process and can influence the establishment of long-term relationships between the parties involved (Djelassi et al. 2018). Most financial institutions do not take advantage of customer self-service potential because they base their assumptions on an incomplete business model in the area of remote service. Remote financial management support services are focused on the speed of response to reported needs, reducing service time, convenience for customers and lowering costs for the service provider (Boon-itt 2015). Innovation in finance may go hand in hand with consumer discomfort arising from lack of control over modern tools, uncertainty of their knowledge and skills, lack of confidence in technology and a sense of technological overwhelm (Parasurman 2000).

One of the objectives of using modern technologies is to support consumer decision-making processes and adapt modern financial services to evolving needs (Buettner 2017; Nitin et al. 2019). Robo-advice facilitates management by providing potential investors with investment guidelines regarding the benefits of investing. Implementing a new path of communication with the recipient requires in-depth research into consumer behaviour, knowledge of which is necessary not only when it comes to understanding purchasing decisions, but also in order to create tailor-made products and predict the future evolution of customers' decisions (Mazurek, Maz 2019). Analysis of consumer attitudes significantly affects preferences and further predictions based on the personality of the user (Blackwell et al. 2005). The assessment of alternatives in the financial decision making process (Beckett et al. 2000) is a multi-stage process, which consists of (a) forming opinions on possible methods of satisfying needs, (b) shaping attitudes towards them and (c) establishing a purchase. This scheme draws on previously accumulated information and experience. Therefore, the challenge is the diagnosis of which determinants may be significant to the consumer in order to shift financial management towards robo-advice. The implementation of modern technologies in the process of personal finance management offers a number of challenges in the area of data circulation and analysis, digitisation and the automation of manual processes, as well as big data architecture.

The purpose of the article is to diagnose the sociological and economic determinants underlying consumer satisfaction in terms of planning personal finances using modern technologies. The paper is organised as follows. At the beginning the article presents the research methodology, after which the authors outline the main results of their worldwide survey. Subsequently, the discussion of the results is shown, whereupon the authors conclude by listing limitations and offering future research options.

\section{Methodology}

The statistical material used in the article stems from the ING International Survey - New Technologies 2019. This online survey was carried out by Ipsos from 30 January to 11 February 2019. Sampling reflects gender ratios and age distribution, selecting from pools of possible respondents furnished by panel providers in each country. European consumer figures are expressed as an average, weighted to take the varying populations of the countries into account. 14,824 respondents from 15 countries (Austria, Belgium, Czech Republic, Germany, France, Italy, Luxembourg, Netherlands, Poland, Romania, Spain, Turkey, United Kingdom, USA, Australia) were involved in 
Make your research more visible, join the Twitter account of ENTREPRENEURSHIP AND SUSTAINABILITY ISSUES: @Entrepr69728810

the survey. The article uses data for Poland made available directly by ING Bank Śląski economists for scientific purposes. 14,824 respondents were surveyed, whose descriptive statistics are presented in Table 1.

Table 1. Descriptive statistics of the studied population $(\mathrm{N}=14,824)$

\begin{tabular}{|c|c|c|c|c|c|c|c|c|c|c|c|c|c|c|c|c|}
\hline \multirow[t]{2}{*}{ Characteristics } & \multirow[t]{2}{*}{$\begin{array}{l}\text { Variants of the } \\
\text { characteristics }\end{array}$} & $\begin{array}{l}\text { D } \\
\text { D. } \\
\text { E. } \\
\text {. }\end{array}$ & 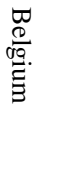 & 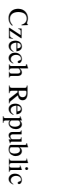 & 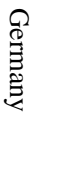 & 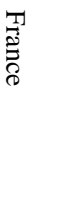 & $\overrightarrow{\overrightarrow{\tilde{\Sigma}}}$ & 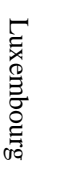 & 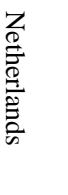 & $\frac{\overrightarrow{0}}{\hat{\tilde{c}}}$ & 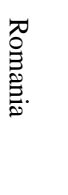 & $\begin{array}{l}\tilde{O} \\
\stackrel{\tilde{O}}{\Xi} .\end{array}$ & 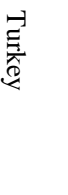 & 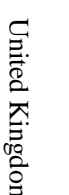 & $\begin{array}{c}c \\
D \\
D\end{array}$ & 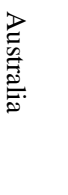 \\
\hline & & $\mathrm{N}$ & $\mathrm{N}$ & $\mathrm{N}$ & $\mathrm{N}$ & $\mathrm{N}$ & $\mathrm{N}$ & $\mathrm{N}$ & $\mathrm{N}$ & $\mathrm{N}$ & $\mathrm{N}$ & $\mathrm{N}$ & $\mathrm{N}$ & $\mathrm{N}$ & $\mathrm{N}$ & $\mathrm{N}$ \\
\hline \multirow{4}{*}{ Age } & $18-35$ & 221 & 199 & 284 & 181 & 179 & 174 & 129 & 194 & 268 & 298 & 190 & 396 & 180 & 230 & 149 \\
\hline & $36-45$ & 257 & 266 & 341 & 277 & 283 & 310 & 197 & 275 & 245 & 381 & 332 & 358 & 299 & 247 & 240 \\
\hline & $46-65$ & 430 & 376 & 332 & 408 & 357 & 418 & 254 & 311 & 416 & 311 & 413 & 243 & 353 & 367 & 343 \\
\hline & Over 66 & 99 & 174 & 78 & 139 & 192 & 105 & 69 & 234 & 87 & 36 & 66 & 14 & 184 & 160 & 275 \\
\hline \multirow{2}{*}{ Gender } & Female & 516 & 516 & 521 & 523 & 517 & 504 & 312 & 519 & 537 & 524 & 507 & 513 & 500 & 510 & 504 \\
\hline & Male & 491 & 499 & 514 & 482 & 494 & 503 & 337 & 495 & 479 & 502 & 494 & 498 & 516 & 494 & 503 \\
\hline \multirow{5}{*}{ Employment } & Student & 52 & 62 & 71 & 51 & 50 & 61 & 44 & 40 & 41 & 59 & 47 & 111 & 28 & 27 & 30 \\
\hline & Unemployed & 100 & 219 & 104 & 151 & 99 & 212 & 41 & 198 & 93 & 152 & 203 & 80 & 197 & 193 & 190 \\
\hline & Employed & 543 & 438 & 650 & 513 & 545 & 462 & 396 & 482 & 626 & 621 & 581 & 692 & 519 & 506 & 420 \\
\hline & Self-employed & 58 & 33 & 59 & 39 & 43 & 115 & 29 & 57 & 74 & 79 & 55 & 46 & 58 & 62 & 66 \\
\hline & Retired & 254 & 263 & 151 & 251 & 274 & 157 & 139 & 237 & 182 & 115 & 115 & 82 & 214 & 216 & 301 \\
\hline \multirow{6}{*}{ Household } & 1 person & 235 & 230 & 134 & 222 & 295 & 106 & 92 & 262 & 94 & 81 & 83 & 41 & 217 & 190 & 223 \\
\hline & 2 people & 392 & 352 & 334 & 377 & 419 & 265 & 213 & 396 & 256 & 278 & 268 & 123 & 358 & 358 & 412 \\
\hline & 3 people & 197 & 226 & 274 & 201 & 153 & 293 & 145 & 174 & 263 & 316 & 304 & 293 & 194 & 189 & 186 \\
\hline & 4 people & 128 & 137 & 200 & 145 & 110 & 261 & 142 & 122 & 258 & 232 & 271 & 335 & 174 & 155 & 121 \\
\hline & 5 people & 40 & 46 & 64 & 44 & 25 & 72 & 44 & 43 & 103 & 78 & 59 & 163 & 53 & 64 & 40 \\
\hline & 6 or more & 15 & 24 & 29 & 16 & 9 & 10 & 13 & 17 & 42 & 41 & 16 & 56 & 20 & 48 & 25 \\
\hline \multirow{5}{*}{ Education } & Primary & 69 & 46 & 65 & 62 & 185 & 105 & 42 & 266 & 27 & 124 & 102 & 161 & 215 & 273 & 284 \\
\hline & Secondary & 489 & 443 & 625 & 375 & 382 & 529 & 201 & 381 & 500 & 112 & 274 & 130 & 305 & 236 & 245 \\
\hline & Vocational & 245 & 267 & 136 & 172 & 216 & 51 & 167 & 223 & 58 & 523 & 165 & 90 & 151 & 166 & 174 \\
\hline & BA & 82 & 132 & 68 & 214 & 84 & 270 & 115 & 47 & 123 & 180 & 328 & 493 & 233 & 225 & 200 \\
\hline & MA & 122 & 127 & 141 & 182 & 144 & 52 & 124 & 97 & 308 & 87 & 132 & 137 & 112 & 104 & 104 \\
\hline Income (euro) & $0-249$ & 13 & 9 & 15 & 17 & 7 & 10 & 2 & 6 & 39 & 77 & 8 & 23 & 18 & 22 & 20 \\
\hline
\end{tabular}




\section{ENTREPRENEURSHIP AND SUSTAINABILITY ISSUES}

ISSN 2345-0282 (online) http://jssidoi.org/jesi/ 2020 Volume 8 Number 2 (December)

http://doi.org/10.9770/jesi.2020.8.2(24)

Make your research more visible, join the Twitter account of ENTREPRENEURSHIP AND SUSTAINABILITY ISSUES: @Entrepr69728810

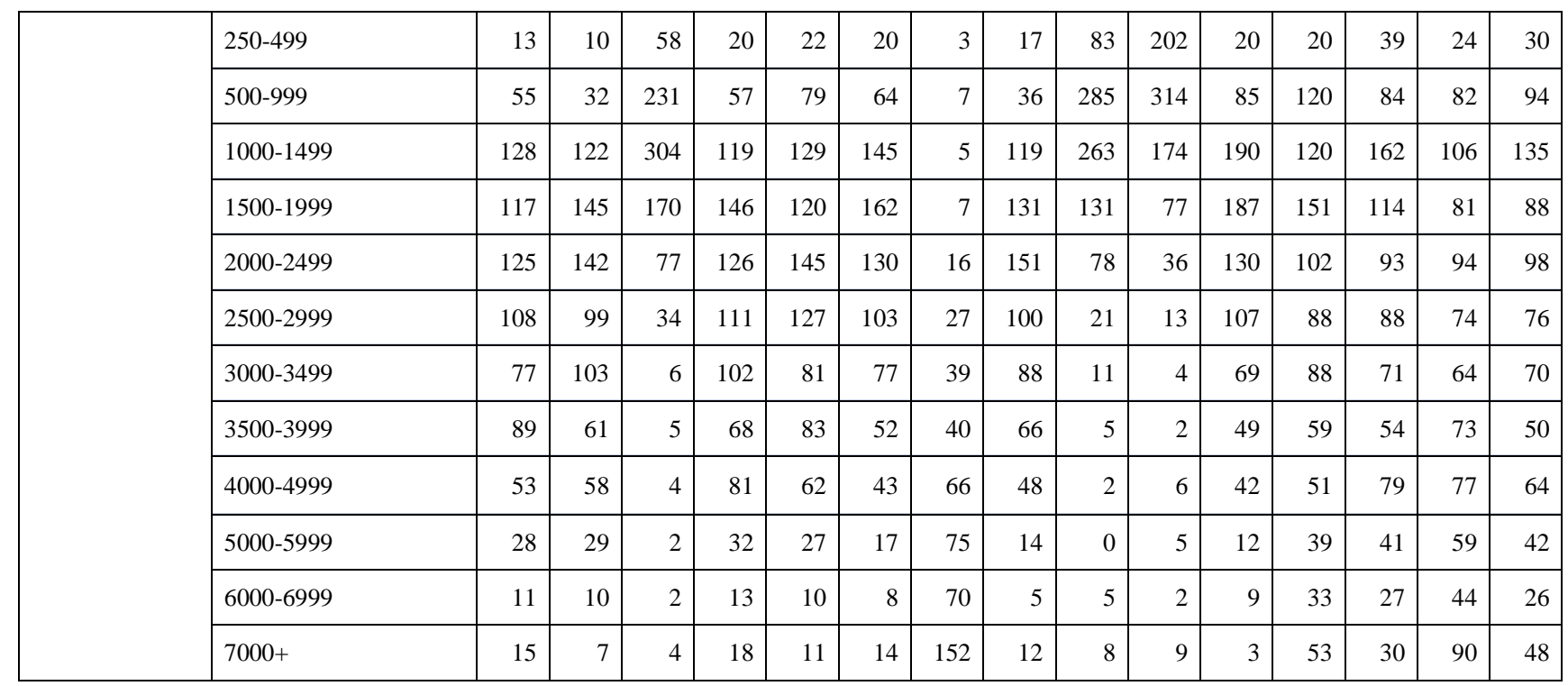

Source: ING International Survey - New Technologies (2019).

Regarding the use of modern technologies in personal financial management, the respondents were presented with two statements to evaluate their level of satisfaction:

1) I would be happy for a computer program to make investment decisions on my behalf.

2) I would be happy for a computer program to analyse my spending habits and recommend improvements.

The respondents responded to these statements on a 5-point Likert scale: 1 - totally disagree, 2 - disagree, 3 difficult to say, 4 -agree, 5 - totally agree.

In order to analyse the date, the following statistical methods were employed:

1) The Chi-square test for independence: a nonparametric method for testing the relationship between two variables expressed on a qualitative scale. These were socio-demographic variables with 2 questions on a 5-point scale.

2) The Mann-Whitney U test: a nonparametric test for studying the differences between 2 groups. In this case, Poland is compared with each country in turn, and the average acceptance value of robo-advice in terms of qualitative sociodemographic variables (gender, work) was compared in different countries.

3) Spearman's rho correlation coefficient: a nonparametric test used to examine the relationship between two variables expressed on the ordinal scale. Applied to the relationship between the survey and sociodemographic questions that were graded (rated on a scale from the lowest to the highest).

The following research hypotheses were formulated:

H1: There are statistically significant differences between Poland and the other countries analysed (apart from Italy and Spain) in terms of the acceptance of robo-advice for making investment decisions as well as for a computer program to analyse expenditure and suggest improvements.

$\mathrm{H} 2$ : In most of the countries studied, age is associated with a lower acceptance for a computer program to make investment decisions, analyse expenditure and recommend improvements.

H3: In most countries, the willingness to allow a computer program to make investment decisions - along with the willingness for a computer program to analyse spending habits and recommend improvements is proportional to the number of people in the household.

H4: Acceptance for a computer to make investment decisions, analyse expenditure and recommend improvements is inversely proportional to age. 
ENTREPRENEURSHIP AND SUSTAINABILITY ISSUES

ISSN 2345-0282 (online) http://jssidoi.org/jesi/

2020 Volume 8 Number 2 (December)

http://doi.org/10.9770/jesi.2020.8.2(24)

Make your research more visible, join the Twitter account of ENTREPRENEURSHIP AND SUSTAINABILITY ISSUES: @Entrepr69728810

H5: Most countries feature statistically significant differences between men and women in terms of accepting robo-advice for investment and there is no difference in terms of accepting a computer program to make expenditure analysis and recommend improvements (apart from Germany, the Netherlands and Turkey).

H6: In most countries there are differences between working and non-working people in terms of accepting robo-advice for investment or as a means of analysing expenses and suggesting improvements.

\section{Research background}

Table 2 presents the most significant robo-advisor parameters in Europe. Assets under management in Europe amounts to USD 49,471m in 2020 in the robo-advisor segment. Assets under management are expected to show an annual growth rate (CAGR 2020-2023) of 35.2\% resulting in a total amount of USD 122,312 million by 2023. In the robo-advisor segment, the number of users is expected to amount to 4,005.1 thousand by 2023 from 2,173 thousand in 2020. The average assets under management per user in the robo-advisor segment amounts to USD 22,767 in 2020 and is expected to grow to USD 30,539.

Table 2. Robo-advisors in Europe

\begin{tabular}{|l|r|r|r|r|r|r|r|}
\hline Key characteristics & 2017 & 2018 & 2019 & 2020 & 2021 & 2022 & 2023 \\
\hline Assets under Management (in million USD) & 7365,0 & 15925,0 & 30052,0 & 49471,0 & 72689,0 & 97626,0 & 122312,0 \\
\hline $\begin{array}{l}\text { Assets under Management Growth (in } \\
\text { percentages) }\end{array}$ & - & 116,20 & 88,70 & 64,60 & 46,90 & 34,30 & 25,30 \\
\hline Users in thousands & 562,90 & 962,50 & 1509,10 & 2173,00 & 2891,30 & 3506,20 & 4005,10 \\
\hline Penetration Rate (in percentages) & 0,10 & 0,10 & 0,20 & 0,30 & 0,30 & 0,40 & 0,50 \\
\hline Assets under Management per User in USD & 13085,0 & 16546,0 & 19914,0 & 22767,0 & 25141,0 & 27844,0 & 30539,0 \\
\hline
\end{tabular}

Source: Statista.com (2020).

Note: penetration rate is the share of active paying customers (or accounts) from the total population of the selected market (market segment, region) for each year.

Taking into account only the 15 countries studied, assets under management by robo-advisors are presented in Fig. 1. According to data for 2020, the total value of these assets amounted to USD 43,032.0 million projected to rise by 2023 to a level of 106,590.0 million USD. The largest markets were Germany and the United Kingdom, accounting for $32 \%$ and $52 \%$ of assets under management respectively of all the countries surveyed. 
Make your research more visible, join the Twitter account of ENTREPRENEURSHIP AND SUSTAINABILITY ISSUES: @Entrepr69728810

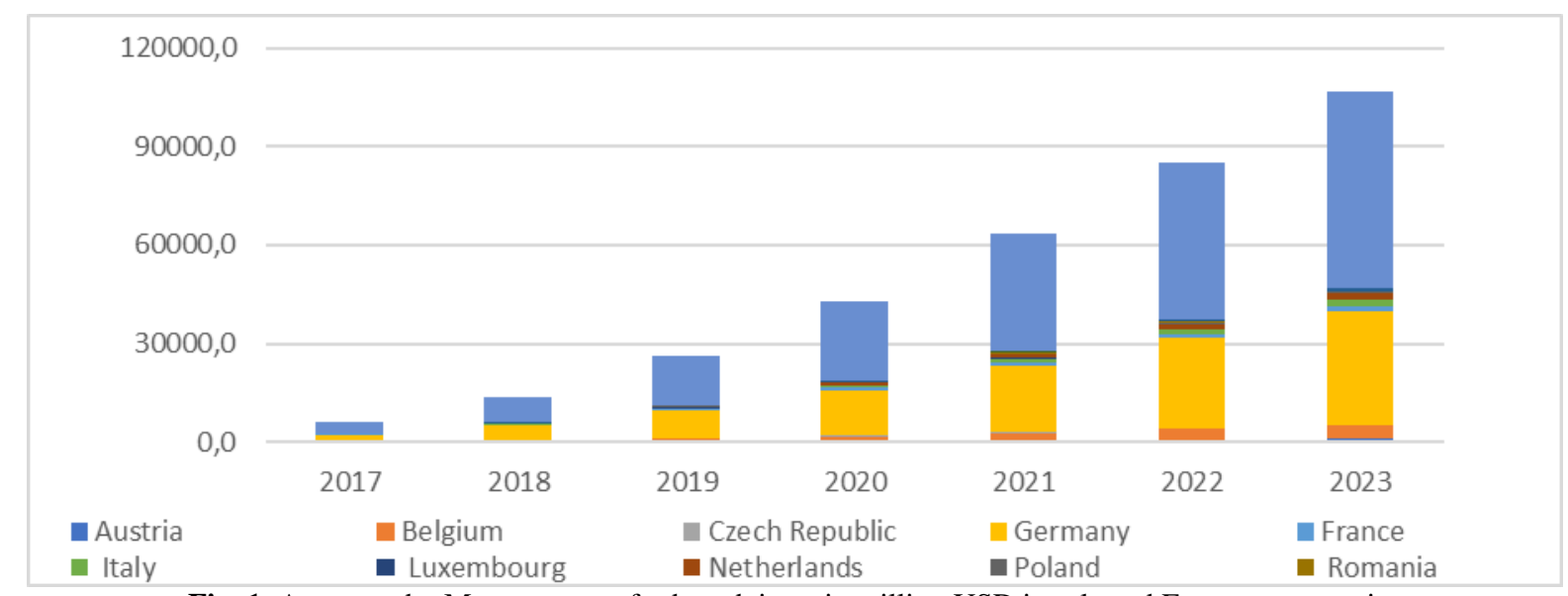

Fig. 1. Assets under Management of robo-advisors in million USD in selected European countries Source: Statista.com (2020)

Taking into account the users of robo-advisors in the 15 European countries surveyed (Fig. 2), in 2020 there were 1635.00 thousand projected to rise by 2023 to 2867.3 thousand. Most users of this service are in Germany and the United Kingdom, accounting for $27 \%$ and $46 \%$ respectively of all users among the countries surveyed.

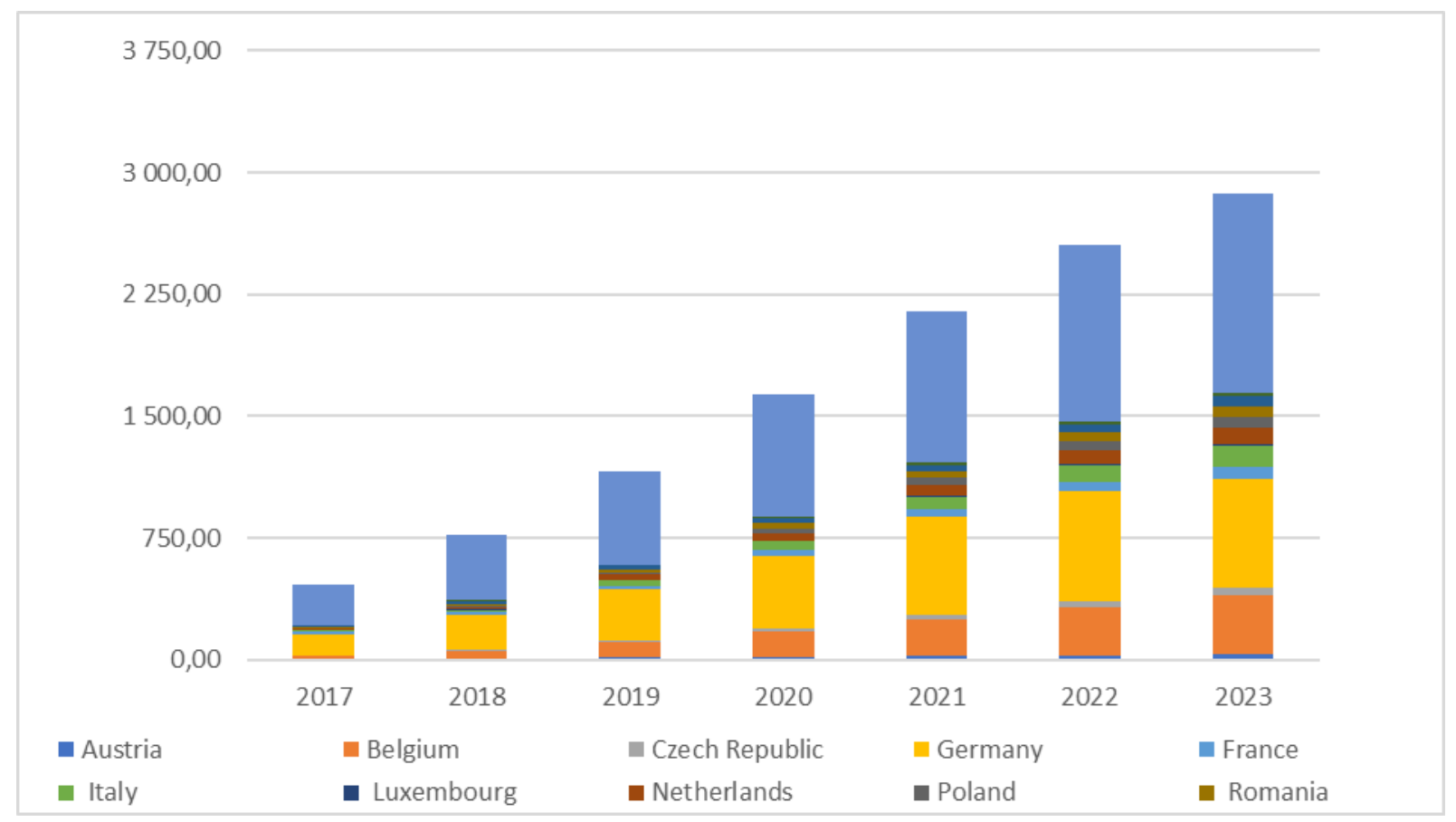

Fig. 2. Users of robo-advisors in thousands in selected European countries Source: Statista.com (2020)

Fig. 3 and 4 present the structure of answers to 2 questions presented to the respondents. The first question concerned financial robo-advice supporting investment decisions. In the case of the European countries studied, the average of the responses was $18 \%$ agree, $21 \%$ neither agree or disagree and $61 \%$ disagree. Countries with the greatest levels of satisfaction with financial robo-advice include Turkey (30\%), Romania (21\%), Czech Republic 
ENTREPRENEURSHIP AND SUSTAINABILITY ISSUES

ISSN 2345-0282 (online) http://jssidoi.org/jesi/

2020 Volume 8 Number 2 (December)

http://doi.org/10.9770/jesi.2020.8.2(24)

Make your research more visible, join the Twitter account of ENTREPRENEURSHIP AND SUSTAINABILITY ISSUES: @Entrepr69728810

(20\%), UK (19\%), Poland (18\%) as well as Spain and Italy (17\%). For the USA, $22 \%$ responded 'agree'. The second question concerned satisfaction a computer program analysing spending habits and suggesting improvements (Fig. 2). For the second question, the percentage of those satisfied was higher than the first. The average 'agree' response for the European countries studied was 38\%, and the highest level of satisfaction was indicated by respondents from Turkey (65\%), Romania (53\%), Poland (45\%), Czech Republic (42\%), Spain (41\%), Luxembourg (35\%) and the UK (34\%). In the case of the USA, the percentage of respondents indicating satisfaction was the same as the European countries studied and amounted to $38 \%$.

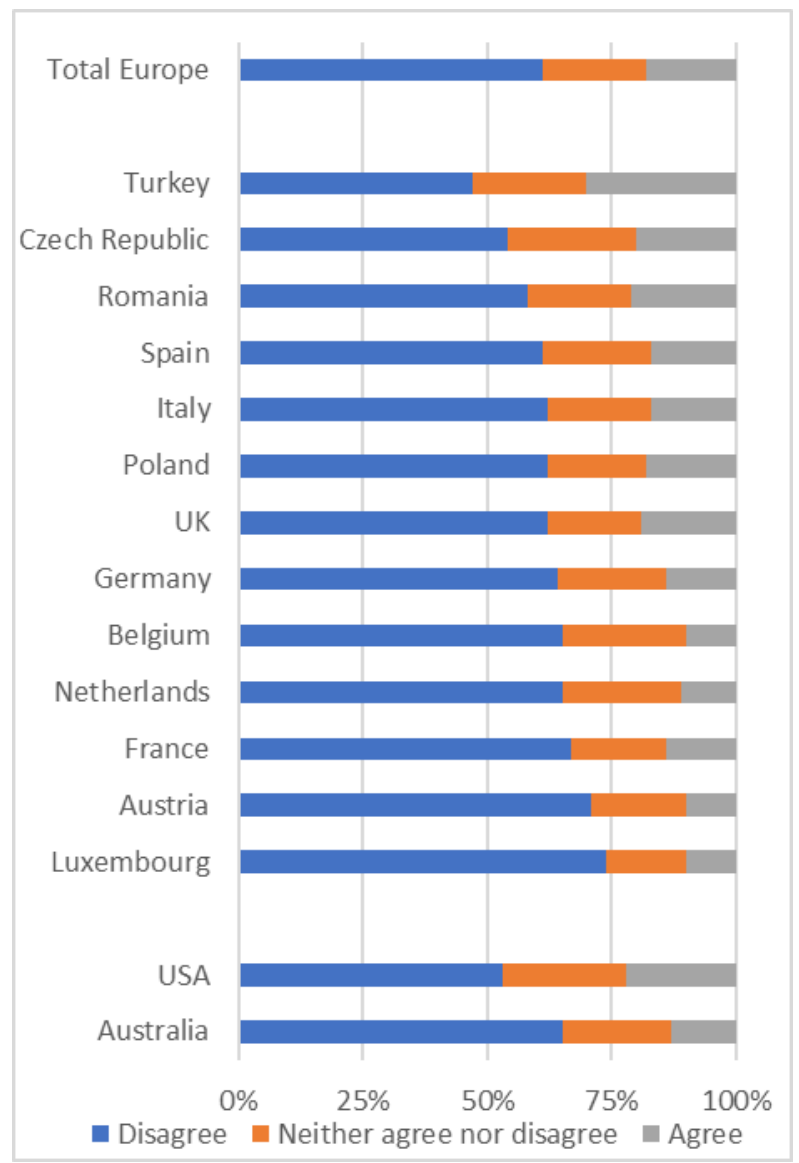

Fig. 3. I would be happy for a computer program to make investment decisions on my behalf

Source: ING International Survey - New Technologies (2019); Note: The 'disagree' category includes 'totally disagree' and 'disagree', and the 'agree' category includes 'totally agree' and 'agree'.

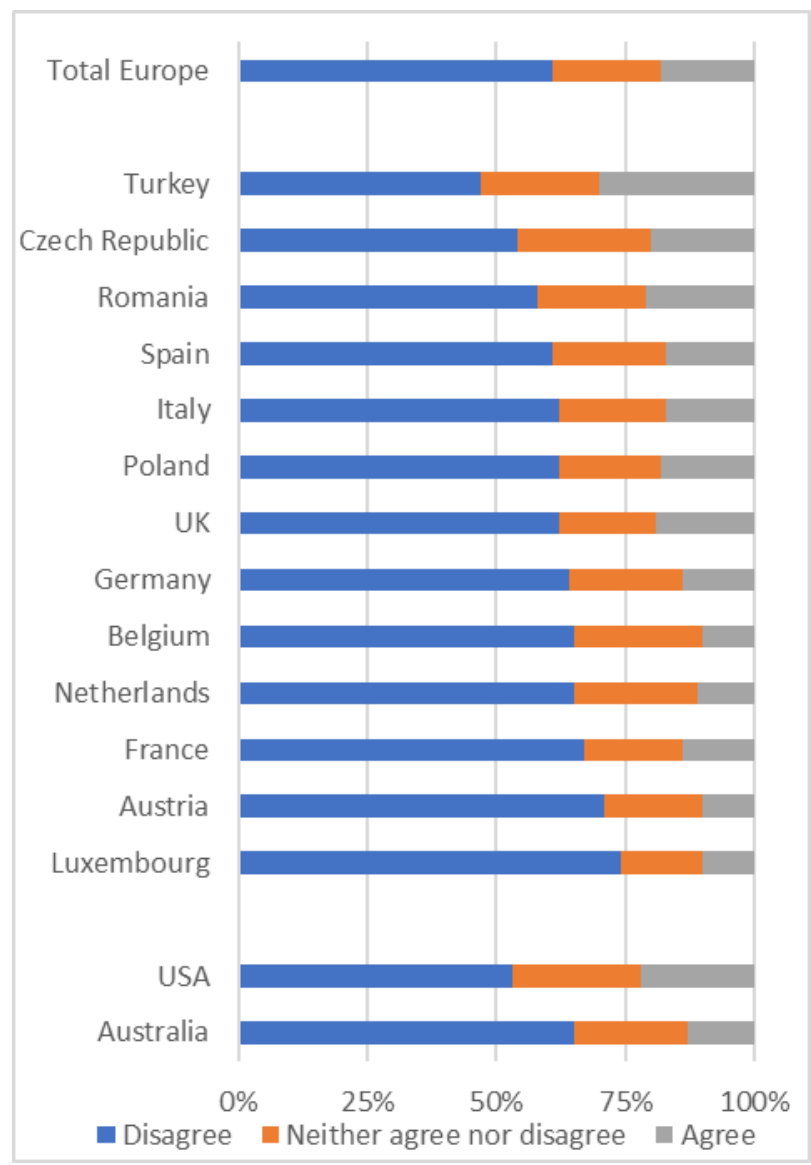

Fig. 4. I would be happy for a computer program to analyse my spending habits and recommend improvements Source: ING International Survey - New Technologies (2019).

Subsequently, in the first stage of the study, the Poles' opinion on financial robo-advice was compared with the opinion of residents of other countries in this respect. Comparative analyses were performed using a series of Mann-Whitney U tests. Table 3 presents the results of the comparative analyses together with descriptive statistics for opinions on financial robo-advice for making investment decisions by country. 
ENTREPRENEURSHIP AND SUSTAINABILITY ISSUES

ISSN 2345-0282 (online) http://jssidoi.org/jesi/

2020 Volume 8 Number 2 (December)

http://doi.org/10.9770/jesi.2020.8.2(24)

Make your research more visible, join the Twitter account of ENTREPRENEURSHIP AND SUSTAINABILITY ISSUES: @Entrepr69728810

Table 3. Descriptive statistics for opinions on financial robo-advice for making investment decisions by country and the results of comparative analyses via Mann-Whitney U tests

\begin{tabular}{|c|c|c|c|c|c|}
\hline I would be happy for a computer program to make investment decisions on my behalf & $M$ & $S D$ & $Z$ & $p$ & $r$ \\
\hline Poland & 2,35 & 1,16 & & - & \\
\hline Australia & 2,11 & 1,11 & 4,69 & $* * *$ & 0,10 \\
\hline Austria & 1,93 & 1,09 & 8,87 & $* * *$ & 0,20 \\
\hline Belgium & 2,11 & 1,08 & 4,52 & $* * *$ & 0,10 \\
\hline Czech Republic & 2,50 & 1,10 & 3,54 & $* * *$ & 0,08 \\
\hline France & 2,09 & 1,17 & 5,63 & $* * *$ & 0,13 \\
\hline Germany & 2,11 & 1,20 & 5,20 & $* * *$ & 0,12 \\
\hline Italy & 2,28 & 1,18 & 1,53 & 0,126 n.s. & 0,03 \\
\hline Luxembourg & 2,01 & 1,03 & 5,83 & $* * *$ & 0,14 \\
\hline Netherlands & 2,12 & 1,08 & 4,21 & $* * *$ & 0,09 \\
\hline Romania & 2,49 & 1,24 & 2,35 & $*$ & 0,05 \\
\hline Spain & 2,29 & 1,19 & 1,43 & 0,152 n.s. & 0,03 \\
\hline Turkey & 2,78 & 1,31 & 7,43 & $* * *$ & 0,17 \\
\hline UK & 2,23 & 1,25 & 3,21 & $* *$ & 0,07 \\
\hline USA & 2,48 & 1,25 & 2,11 & $*$ & 0,05 \\
\hline
\end{tabular}

M-mean, SD - standard deviation, Me - median, $Z-U$ Mann-Whitney statistic, $p$ - level of statistical significance, $r-$ strength of effects, ${ }^{*} p<0,05, * * p<0,01, * * * p<0,001$, n.s. - statistically insignificant

The results of the Mann-Whitney $U$ tests proved to be statistically significant, which means that there were differences between Poland and the other countries in terms of acceptance of robo-advice for making investment decisions. Only statistically significant differences between Poland and Italy were not indicated $Z=1.53 ; \mathrm{p}=$ $0.126 ; \mathrm{V}=0.03$ and Spain $\mathrm{Z}=1.11 ; \mathrm{p}=0.265 ; \mathrm{V}=0.03$.

Countries featuring a higher level of acceptance of investment advice for investments included Turkey, the Czech Republic, Romania and the USA. Other countries indicated a lower rate of acceptance of this advisory function, and the lowest value was found for Austria and Luxembourg. Based on the r strength of effect ratio, it can be concluded that the differences were most marked between Poland and Australia and Luxembourg.

Similarly, by means of a series of multiple comparisons via Mann-Whitney $U$ tests, a study was conducted into whether and how Poles differed from other nationalities in terms of robo-advice given by a computer program for analysing expenses and suggesting improvements. 
ENTREPRENEURSHIP AND SUSTAINABILITY ISSUES

ISSN 2345-0282 (online) http://jssidoi.org/jesi/

2020 Volume 8 Number 2 (December)

http://doi.org/10.9770/jesi.2020.8.2(24)

Make your research more visible, join the Twitter account of ENTREPRENEURSHIP AND SUSTAINABILITY ISSUES: @Entrepr69728810

Table 4. Descriptive statistics for opinions on financial robo-advice in terms of analysing habits related to expenditure by country and the results of comparative analyses via Mann-Whitney $\mathrm{U}$ tests

\begin{tabular}{ccccccc}
\hline $\begin{array}{c}\text { I would be happy for a computer program to analyse my spending habits } \\
\text { and recommend improvements }\end{array}$ & $M$ & $S D$ & $Z$ & $p$ & $r$ \\
\hline Poland & 3,23 & 1,14 & & - & \\
Australia & 2,66 & 1,19 & 10,49 & $* * *$ & 0,23 \\
Austria & 2,55 & 1,29 & 11,97 & $* * *$ & 0,27 \\
Belgium & 2,71 & 1,17 & 9,77 & $* * *$ & 0,22 \\
Czech Republic & 3,11 & 1,16 & 2,19 & $*$ & 0,05 \\
France & 2,71 & 1,30 & 9,15 & $* * *$ & 0,20 \\
Germany & 2,55 & 1,30 & 11,93 & $* * *$ & 0,26 \\
Italy & 2,98 & 1,17 & 4,62 & $* * *$ & 0,10 \\
Luxembourg & 2,82 & 1,26 & 6,49 & $* * *$ & 0,16 \\
Netherlands & 2,66 & 1,12 & 10,93 & $* * *$ & 0,24 \\
Romania & 3,44 & 1,23 & 4,40 & $* * *$ & 0,10 \\
Spain & 3,09 & 1,24 & 2,39 & $*$ & 0,05 \\
Turkey & 3,80 & 1,15 & 11,43 & $* * *$ & 0,25 \\
UK & 2,77 & 1,28 & 8,10 & $* * *$ & 0,18 \\
USA & 2,99 & 1,28 & 4,12 & $* * *$ & 0,09
\end{tabular}

$M$ - mean, SD - standard deviation, Me - median, $Z$ - U Mann-Whitney statistic, $p$ - level of statistical significance, $r$ - strength effects, ${ }^{*} p<0,05, * * p<0,01, * * * p<0,001$, n.s. - statistically insignificant

All results of the Mann-Whitney $U$ analyses turned out to be statistically significant $p<0.001$. Therefore, citizens of different nationalities differed in their willingness for a computer to analyse their expenditure. Turkey and Romania featured a higher level of acceptance of robo-advice for spending analysis than Poland. The greatest reluctance to have a computer program give financial advice was expressed by the inhabitants of Austria and Germany.

Next, a study was conducted as to whether acceptance of robo-advice was related in different degrees to sociodemographic variables in Poland and other countries. Spearman's rho correlation analysis was used for variables measured on the ordinal scale. Table 5 presents the results of correlation analyses for the relationship between sociodemographic variables and the acceptance of financial robo-advice for making investment decisions by country. 
Make your research more visible, join the Twitter account of ENTREPRENEURSHIP AND SUSTAINABILITY ISSUES: @Entrepr69728810

Table 5. Results of Spearman's rho correlation analysis for the relationship between sociodemographic variables and acceptance of financial robo-advice for making investment decisions by country

\begin{tabular}{|c|c|c|c|c|}
\hline $\begin{array}{l}\text { I would be happy for a } \\
\text { computer program to make } \\
\text { investment decisions on my } \\
\text { behalf }\end{array}$ & Age & Qualification & Number of people in the household & Income \\
\hline Poland & $-0,03$ & $-0,02$ & $0,07 *$ & $-0,03$ \\
\hline Australia & $-0,34 * * *$ & $0,09 * *$ & $0,15^{* * * *}$ & 0,04 \\
\hline Austria & $-0,10 * * *$ & 0,05 & $0,11^{* * *}$ & $-0,07 *$ \\
\hline Belgium & $-0,18 * * *$ & $-0,04$ & $0,12 * * *$ & $-0,03$ \\
\hline Czech Republic & 0,00 & $-0,02$ & 0,04 & $-0,01$ \\
\hline France & $-0,21 * * *$ & $0,07^{*}$ & $0,14 * * *$ & 0,01 \\
\hline Germany & $-0,23 * * *$ & $0,11^{* * *}$ & $0,12 * * *$ & 0,06 \\
\hline Italy & $-0,10 * *$ & $0,08^{*}$ & $0,10^{* *}$ & $0,08^{*}$ \\
\hline Luxembourg & $-0,13 * * *$ & $-0,05$ & 0,05 & $-0,09 *$ \\
\hline Netherlands & $-0,19 * * *$ & $0,14 * * *$ & $0,16^{* * *}$ & $0,15^{* * * *}$ \\
\hline Romania & $-0,08 * *$ & $-0,13 * * *$ & 0,03 & $-0,09 * *$ \\
\hline Spain & $-0,11 * * *$ & $0,12^{* * *}$ & $0,11^{* * *}$ & 0,04 \\
\hline Turkey & 0,05 & $0,13^{* * *}$ & $0,07 *$ & $0,17 * * *$ \\
\hline UK & $-0,36 * * *$ & 0,06 & $0,19 * * *$ & 0,06 \\
\hline USA & $-0,34 * * *$ & $-0,01$ & $0,13^{* * *}$ & $-0,02$ \\
\hline
\end{tabular}

The results of correlation analyses demonstrate that in most countries age was associated with a decrease in acceptance for a computer program to make investment decisions. In the United Kingdom, the strongest relationship in this respect was $\rho=-0.36 ; p<0.001$, then the USA $\rho=-0.34 ; p<0.001$ and Australia $\rho=-0.34 ; p$ $<0.001$. Furthermore, in most countries, the willingness for a computer program to make investment decisions was proportional to the number of people in the household. In the United Kingdom, the strongest relationship in this respect was $\rho=0.19 ; \mathrm{p}<0.001$.

In the case of countries such as Italy, the Netherlands and Turkey, high acceptance for a computer program to make investment decisions was demonstrated to be associated with higher levels of education and income. It is interesting that the exact opposite relationship occurred in the case of Romania. 
Make your research more visible, join the Twitter account of ENTREPRENEURSHIP AND SUSTAINABILITY ISSUES: @Entrepr69728810

Table 6. Results of Spearman's rho correlation analysis for the relationship between sociodemographic variables and acceptance of financial robo-advice in analysing spending habits by country

\begin{tabular}{|c|c|c|c|c|}
\hline $\begin{array}{l}\text { I would be happy for a } \\
\text { computer program to analyse } \\
\text { my spending habits and } \\
\text { recommend improvements }\end{array}$ & Age & Qualification & Number of people in the household & Income \\
\hline Poland & $-0,24 * * *$ & $-0,02$ & $0,11 * * *$ & $-0,04$ \\
\hline Australia & $-0,32 * * *$ & $0,08 *$ & $0,14 * * *$ & 0,06 \\
\hline Austria & $-0,15 * * *$ & $-0,033$ & $0,13 * * *$ & $-0,02$ \\
\hline Belgium & $-0,18 * * *$ & $-0,07 *$ & $0,08 *$ & $-0,01$ \\
\hline Czech Republic & $-0,13 * * *$ & $-0,06^{*}$ & 0,06 & 0,02 \\
\hline France & $-0,21 * * *$ & $-0,015$ & $0,15 * * *$ & 0,00 \\
\hline Germany & $-0,23 * * *$ & $0,08 * *$ & $0,12 * * *$ & $0,07 *$ \\
\hline Italy & $-0,19 * * *$ & 0,06 & $0,14 * * *$ & $0,07^{*}$ \\
\hline Luxembourg & $-0,17 * * *$ & $-0,04$ & $0,10 * *$ & $-0,10^{*}$ \\
\hline Netherlands & $-0,20 * * *$ & $0,13 * * *$ & $0,17 * * *$ & $0,15 * * *$ \\
\hline Romania & $-0,12 * * *$ & $-0,12 * * *$ & 0,04 & $-0,11 * *$ \\
\hline Spain & $-0,22 * * *$ & $0,07 *$ & $0,13 * * *$ & 0,06 \\
\hline Turkey & $-0,10 * *$ & $0,17 * * *$ & $0,13 * * *$ & $0,20 * *$ \\
\hline UK & $-0,37 * * *$ & $0,07 *$ & $0,19 * * *$ & $0,10^{* *}$ \\
\hline USA & $-0,31 * * *$ & $-0,01$ & $0,20 * * *$ & $-0,01$ \\
\hline
\end{tabular}

For all the countries studied, correlation analyses revealed that as age increased, the acceptance of a computer analysing expenses and recommending improvements decreased. The strongest relationships in this area were also shown by the United Kingdom $\rho=-0.37 ; p<0.001$, then the USA $\rho=-0.31 ; p<0.001$ and Australia $\rho=-0.32 ; p$ $<0.001$, with Turkey having the weakest $\rho=-0.10 ; \mathrm{p}<0.01$. Also in most countries, the number of people in the household proved to be proportional to the willingness for a computer program to analyse spending habits and recommend improvements. This relationship was also the strongest in the United Kingdom $\rho=0.19 ; \mathrm{p}<0.001$ and the USA $\rho=0.20 ; \mathrm{p}<0.001$.

Further analysis indicated that for countries such as Germany, the Netherlands, Turkey and the United Kingdom, high acceptance for a computer program to analyse expenditure was associated with higher education and income levels. Romania is the only case where people with a university degree and higher earnings are less willing to have a computer analyse expenses and recommend improvements.

A study was also conducted as to which countries featured a differentiated level of acceptance of financial advice by gender. For this purpose, comparative analyses were carried out using Mann-Whitney U tests. 


\section{ENTREPRENEURSHIP AND SUSTAINABILITY ISSUES}

ISSN 2345-0282 (online) http://jssidoi.org/jesi/

2020 Volume 8 Number 2 (December)

http://doi.org/10.9770/jesi.2020.8.2(24)

Make your research more visible, join the Twitter account of ENTREPRENEURSHIP AND SUSTAINABILITY ISSUES: @Entrepr69728810

Table 7. Descriptive statistics for opinions on financial robo-advice in terms of making investment decisions by country and gender as well as the results of comparative analyses via Mann-Whitney U tests

\begin{tabular}{|c|c|c|c|c|c|c|c|}
\hline \multirow{2}{*}{$\begin{array}{l}\text { I would be happy for a computer program to make } \\
\text { investment decisions on my behalf }\end{array}$} & \multicolumn{2}{|c|}{ Women } & \multicolumn{2}{|c|}{ Men } & \multirow{2}{*}{$Z$} & \multirow{2}{*}{$p$} & \multirow{2}{*}{$r$} \\
\hline & $M$ & $S D$ & $M$ & $S D$ & & & \\
\hline Poland & 2,34 & 1,15 & 2,36 & 1,17 & 0,28 & 0,780n.s. & 0,01 \\
\hline Australia & 2,03 & 1,04 & 2,20 & 1,17 & 1,97 & $*$ & 0,06 \\
\hline Austria & 1,78 & 0,96 & 2,08 & 1,19 & 3,66 & $* * *$ & 0,12 \\
\hline Belgium & 2,02 & 1,03 & 2,21 & 1,13 & 2,57 & $*$ & 0,08 \\
\hline Czech Republic & 2,46 & 1,05 & 2,53 & 1,16 & 0,91 & 0,363 n.s. & 0,03 \\
\hline France & 2,00 & 1,14 & 2,19 & 1,21 & 2,47 & $*$ & 0,08 \\
\hline Germany & 1,91 & 1,06 & 2,33 & 1,30 & 5,10 & $* * *$ & 0,16 \\
\hline Italy & 2,15 & 1,12 & 2,41 & 1,22 & 3,32 & $* *$ & 0,10 \\
\hline Luxembourg & 1,91 & 1,02 & 2,11 & 1,04 & 2,77 & $* *$ & 0,11 \\
\hline Netherlands & 1,98 & 1,01 & 2,28 & 1,13 & 4,28 & $* * *$ & 0,13 \\
\hline Romania & 2,41 & 1,17 & 2,57 & 1,31 & 1,66 & 0,097n.s. & 0,05 \\
\hline Spain & 2,23 & 1,16 & 2,34 & 1,21 & 1,28 & 0,199n.s. & 0,04 \\
\hline Turkey & 2,79 & 1,31 & 2,78 & 1,32 & 0,10 & 0,924n.s. & 0,00 \\
\hline UK & 2,09 & 1,19 & 2,36 & 1,30 & 3,32 & $* *$ & 0,10 \\
\hline USA & 2,35 & 1,23 & 2,61 & 1,26 & 3,33 & $* *$ & 0,11 \\
\hline
\end{tabular}

$M$ - mean, $S D$ - standard deviation, Me - median, $Z-U$ Mann-Whitney statistic, $p$ - level of statistical significance, $r$ - strength effects, ${ }^{*} p<0,05, * * p<0,01, * * * p<0,001$, n.s. - statistically insignificant

The results of the Mann-Whitney $U$ tests proved to be significant, which means that the countries analysed do feature differences between men and women in terms of accepting robo-advice for investment. No such gender differences were found in Poland $Z=0.28 ; p=0.780 ; r=0.01$, the Czech Republic $Z=0.91 ; p=0.363 ; r=0.03$, Romania $Z=1.66 ; p=0.097 ; r=0.05$, Spain $Z=1.28 ; p=0.199 ; r=0.04$ or Turkey with $Z=0.10 ; p=0.924 ; r=$ 0.00. In all other countries, men were more willing than women to have a computer make investment decisions for them, and the largest gender differences were found among the inhabitants of Germany and Austria. 


\section{ENTREPRENEURSHIP AND SUSTAINABILITY ISSUES}

ISSN 2345-0282 (online) http://jssidoi.org/jesi/

2020 Volume 8 Number 2 (December)

http://doi.org/10.9770/jesi.2020.8.2(24)

Make your research more visible, join the Twitter account of ENTREPRENEURSHIP AND SUSTAINABILITY ISSUES: @Entrepr69728810

Table 8. Descriptive statistics for opinions on financial robo-advice in terms of analysing spending habits by country and gender as well as the results of comparative analyses via Mann-Whitney U tests

\begin{tabular}{|c|c|c|c|c|c|c|c|}
\hline \multirow{2}{*}{$\begin{array}{l}\text { I would be happy for a computer program to analyse my } \\
\text { spending habits and recommend improvements }\end{array}$} & \multicolumn{2}{|c|}{ Women } & \multicolumn{2}{|c|}{ Men } & \multirow{2}{*}{$Z$} & \multirow{2}{*}{$p$} & \multirow{2}{*}{$r$} \\
\hline & $M$ & $S D$ & $M$ & $S D$ & & & \\
\hline Poland & 3,28 & 1,13 & 3,16 & 1,15 & 1,52 & 0,128 n.s. & 0,05 \\
\hline Australia & 2,64 & 1,20 & 2,68 & 1,19 & 0,42 & 0,673 n.s. & 0,01 \\
\hline Austria & 2,50 & 1,26 & 2,60 & 1,32 & 1,04 & 0,296n.s. & 0,03 \\
\hline Belgium & 2,70 & 1,17 & 2,72 & 1,18 & 0,37 & 0,712 n.s. & 0,01 \\
\hline Czech Republic & 3,06 & 1,13 & 3,16 & 1,18 & 1,63 & 0,104 n.s. & 0,05 \\
\hline France & 2,69 & 1,29 & 2,72 & 1,31 & 0,25 & 0,804 n.s. & 0,01 \\
\hline Germany & 2,38 & 1,21 & 2,72 & 1,37 & 3,80 & $* * *$ & 0,12 \\
\hline Italy & 2,95 & 1,18 & 3,01 & 1,17 & 0,89 & 0,373 n.s. & 0,03 \\
\hline Luxembourg & 2,76 & 1,28 & 2,87 & 1,25 & 1,06 & 0,289n.s. & 0,04 \\
\hline Netherlands & 2,54 & 1,13 & 2,78 & 1,10 & 3,59 & $* * *$ & 0,11 \\
\hline Romania & 3,45 & 1,21 & 3,43 & 1,26 & 0,04 & 0,968n.s. & 0,00 \\
\hline Spain & 3,09 & 1,25 & 3,08 & 1,24 & 0,23 & 0,819 & 0,01 \\
\hline Turkey & 3,94 & 1,07 & 3,64 & 1,22 & 3,79 & $* * *$ & 0,12 \\
\hline UK & 2,70 & 1,26 & 2,83 & 1,31 & 1,59 & 0,111 n.s. & 0,05 \\
\hline USA & 2,95 & 1,27 & 3,03 & 1,29 & 1,08 & 0,278 n.s. & 0,03 \\
\hline
\end{tabular}

$M$ - mean, SD - standard deviation, Me - median, $Z$ - U Mann-Whitney statistic, $p$ - level of statistical significance, $r-$ strength effects, $* p<0,05, * * p<0,01, * * * p<0,001$, n.s. - statistically insignificant

The results of the Mann-Whitney U test were mostly insignificant, which means that there were no differences between men and women in the analysed countries in terms of acceptance of robo-advice for analysing expenses and recommending improvements. Such differences were only demonstrated for Germany $Z=3.80 ; p<0.001 ; r=$ 0.12 , the Netherlands $Z=3.59 ; \mathrm{p}<0.001 ; \mathrm{r}=0.11$ and Turkey $\mathrm{Z}=3.79 ; \mathrm{p}<0.001 ; \mathrm{r}=0.12$. In the case of Germany and the Netherlands, men were more likely to have a computer analyse their expenses, while in the case of Turkey, women were more likely to do so. People working (employed or self-employed) were also compared with those not working (at school/at university/retired/unemployed) in terms of their evaluation of financial roboadvice by country. 


\section{ENTREPRENEURSHIP AND SUSTAINABILITY ISSUES}

ISSN 2345-0282 (online) http://jssidoi.org/jesi/

2020 Volume 8 Number 2 (December)

http://doi.org/10.9770/jesi.2020.8.2(24)

Make your research more visible, join the Twitter account of ENTREPRENEURSHIP AND SUSTAINABILITY ISSUES: @Entrepr69728810

Table 9. Descriptive statistics for opinions on financial robo-advice in terms of making investment decisions by country and employment as well as the results of comparative analyses via Mann-Whitney U tests

\begin{tabular}{|c|c|c|c|c|c|c|c|}
\hline \multirow{2}{*}{$\begin{array}{l}\text { I would be happy for a computer program to make } \\
\text { investment decisions on my behalf }\end{array}$} & \multicolumn{2}{|c|}{$\begin{array}{l}\text { Working } \\
\text { people }\end{array}$} & \multicolumn{2}{|c|}{$\begin{array}{l}\text { Non-working } \\
\text { people }\end{array}$} & \multirow{2}{*}{$Z$} & \multirow{2}{*}{$p$} & \multirow{2}{*}{$r$} \\
\hline & $M$ & $S D$ & $M$ & $S D$ & & & \\
\hline Poland & 2,34 & 1,03 & 2,35 & 1,21 & 0,71 & 0,477n.s. & 0,02 \\
\hline Australia & 1,87 & 0,98 & 2,37 & 1,19 & 6,89 & $* * *$ & 0,22 \\
\hline Austria & 1,90 & 1,07 & 1,95 & 1,10 & 0,68 & 0,495 n.s. & 0,02 \\
\hline Belgium & 2,01 & 1,04 & 2,22 & 1,12 & 2,98 & $* *$ & 0,09 \\
\hline Czech Republic & 2,45 & 1,04 & 2,52 & 1,13 & 0,57 & 0,569 n.s. & 0,02 \\
\hline France & 1,86 & 0,97 & 2,28 & 1,28 & 4,71 & $* * *$ & 0,15 \\
\hline Germany & 1,92 & 1,10 & 2,25 & 1,25 & 4,12 & $* * *$ & 0,13 \\
\hline Italy & 2,07 & 1,09 & 2,43 & 1,21 & 4,79 & $* * *$ & 0,15 \\
\hline Luxembourg & 1,90 & 0,94 & 2,07 & 1,07 & 1,70 & 0,089n.s. & 0,07 \\
\hline Netherlands & 1,92 & 0,98 & 2,30 & 1,13 & 5,38 & $* * *$ & 0,17 \\
\hline Romania & 2,39 & 1,18 & 2,54 & 1,26 & 1,61 & 0,107n.s. & 0,05 \\
\hline Spain & 2,11 & 1,12 & 2,39 & 1,21 & 3,51 & $* * *$ & 0,11 \\
\hline Turkey & 2,45 & 1,19 & 2,91 & 1,34 & 4,84 & $* * *$ & 0,15 \\
\hline UK & 1,86 & 1,10 & 2,51 & 1,29 & 8,45 & $* * *$ & 0,26 \\
\hline USA & 2,21 & 1,14 & 2,68 & 1,30 & 5,73 & $* * *$ & 0,18 \\
\hline
\end{tabular}

$M$ - mean, SD - standard deviation, Me - median, Z - U Mann-Whitney statistic, $p$ - level of statistical significance, $r$ - strength effects, ${ }^{*} p<0,05, * * p<0,01, * * * p<0,001$, n.s. - statistically insignificant

The results of the Mann-Whitney $U$ tests proved to be significant for the most part, which means that the countries analysed do feature differences between working and non-working people in terms of their acceptance of robo-advice advice for investment. No such differences were found for Poland $Z=0.71 ; p=0.477 ; \mathrm{r}=0.02$, Austria $Z=0.68 ; p=0.495 ; r=0.02$, Czechs $Z=0.57 ; p=0.569 ; r=0.02$, Luxembourg $Z=1.70 ; p=0.089 ; r=$ 0.07 or Romania $Z=1.61 ; p=0.107 ; r=0.05$. In the remaining countries, it was shown that working people were more favourably inclined to robo-advice for investment and the widest differences were found in the case of the United Kingdom. 


\section{ENTREPRENEURSHIP AND SUSTAINABILITY ISSUES}

ISSN 2345-0282 (online) http://jssidoi.org/jesi/

2020 Volume 8 Number 2 (December)

http://doi.org/10.9770/jesi.2020.8.2(24)

Make your research more visible, join the Twitter account of ENTREPRENEURSHIP AND SUSTAINABILITY ISSUES: @Entrepr69728810

Table 10. Descriptive statistics for opinions on financial robo-advice in terms of analysing spending habits by country and employment as well as the results of comparative analyses via Mann-Whitney U tests

\begin{tabular}{|c|c|c|c|c|c|c|c|}
\hline \multirow{2}{*}{$\begin{array}{l}\text { I would be happy for a computer program to analyse my } \\
\text { spending habits and recommend improvements }\end{array}$} & \multicolumn{2}{|c|}{$\begin{array}{l}\text { Non-Working } \\
\text { people }\end{array}$} & \multicolumn{2}{|c|}{$\begin{array}{l}\text { Working } \\
\text { people }\end{array}$} & \multirow{2}{*}{$Z$} & \multirow{2}{*}{$p$} & \multirow{2}{*}{$r$} \\
\hline & $M$ & $S D$ & $M$ & $S D$ & & & \\
\hline Poland & 3,19 & 1,10 & 3,24 & 1,16 & 0,94 & 0,350n.s. & 0,03 \\
\hline Australia & 2,42 & 1,16 & 2,91 & 1,18 & 6,41 & $* * *$ & 0,20 \\
\hline Austria & 2,50 & 1,24 & 2,59 & 1,32 & 1,02 & 0,309n.s. & 0,03 \\
\hline Belgium & 2,62 & 1,17 & 2,81 & 1,17 & 2,78 & $* * *$ & 0,09 \\
\hline Czech Republic & 3,10 & 1,13 & 3,12 & 1,17 & 0,31 & 0,754 n.s. & 0,01 \\
\hline France & 2,53 & 1,25 & 2,85 & 1,32 & 3,96 & $* * *$ & 0,12 \\
\hline Germany & 2,33 & 1,25 & 2,70 & 1,32 & 4,44 & $* * *$ & 0,14 \\
\hline Italy & 2,82 & 1,18 & 3,10 & 1,16 & 3,79 & $* * *$ & 0,12 \\
\hline Luxembourg & 2,59 & 1,18 & 2,94 & 1,29 & 3,29 & $* *$ & 0,13 \\
\hline Netherlands & 2,48 & 1,11 & 2,81 & 1,11 & 4,78 & $* * *$ & 0,15 \\
\hline Romania & 3,45 & 1,25 & 3,43 & 1,23 & 0,42 & 0,677n.s. & 0,01 \\
\hline Spain & 2,92 & 1,28 & 3,18 & 1,21 & 3,26 & $* *$ & 0,10 \\
\hline Turkey & 3,48 & 1,22 & 3,91 & 1,11 & 5,14 & $* * *$ & 0,16 \\
\hline UK & 2,40 & 1,25 & 3,05 & 1,24 & 8,04 & $* * *$ & 0,25 \\
\hline USA & 2,76 & 1,25 & 3,17 & 1,27 & 5,05 & $* * *$ & 0,16 \\
\hline
\end{tabular}

$M$ - mean, SD - standard deviation, Me - median, $Z-U$ Mann-Whitney statistic, $p$ - level of statistical significance, $r-$ strength effects, $* p<0,05, * * p<0,01, * * * p<0,001$, n.s. - statistically insignificant

The results of the Mann-Whitney $U$ tests again proved to be largely significant, which means that in the countries analysed there were differences between working and non-working people in terms of their acceptance of roboadvice for spending analysis. Such differences were not found in Poland $Z=0.94 ; p=0.350 ; r=0.03$, Austria $Z=$ $1.02 ; p=0.309 ; r=0.03$, Czechs $Z=0.31 ; p=0.754 ; r=0.01$ or Romania $Z=0.42 ; p=0.677 ; r=0.01$. In other countries, working people would be more likely to use robo-advice for spending analysis and recommendations for improvement than non-working people. Here too, the most extreme differences were observed in the United Kingdom. 


\section{ENTREPRENEURSHIP AND SUSTAINABILITY ISSUES}

ISSN 2345-0282 (online) http://jssidoi.org/jesi/

2020 Volume 8 Number 2 (December)

http://doi.org/10.9770/jesi.2020.8.2(24)

Make your research more visible, join the Twitter account of ENTREPRENEURSHIP AND SUSTAINABILITY ISSUES: @Entrepr69728810

\section{Discussion}

Analyses on robo-advice have thus far focused on technical and legal issues, while also attempting to forecast the growth of the robo-advice market (Jl, 2017; Mordor Intelligence 2017; Netscribes 2018; Glaser et al. 2019; EIBIS 2020). This study supplements the research approach with an analysis of how socioeconomic factors impact the use of modern technologies in the process of personal finance management. The study determines the statistical significance and strength of the relationship between the individual socio-demographic characteristics presented by the respondents - such as age, gender, employment, number of people in the household, education, income and their satisfaction with using modern robo-advice technologies in personal finance and a computer program to monitor spending habits and suggest improvements.

In the authors's opinion, interesting conclusions can be drawn from analysis on the impact of psychological and cultural factors on the use of modern technologies to manage personal finances. For the issue in question, this represents a gap in research.

The study gives the following contribution to the literature on the subject: satisfaction with the use of modern technologies in planning personal finances on the example of robo-advice and home budget control depends on socio-demographic variables - age, (except for the control of the home budget by a computer program), income in the household, education, number of people in the household, forms of professional activity.

The direction that further research needs to take is to diagnose why consumers are more satisfied with the use of a computer program to analyse expenditure than with making investment decisions. The study has provided a rationale for analysing the relationship between personality, temperament, risk aversion, sense of security and style of spending.

\section{Conclusion}

Based on the empirical material collected, the International Survey - New Technologies 2019 found that the percentage of respondents indicating their satisfaction with using a computer program to analyse spending habits was higher than in the case of responses about the use of a computer program to make investment decisions on behalf of the consumer.

The analysis results of the Mann-Whitney $U$ tests proved to be statistically significant, which means that there were indeed differences between Poland and the other countries in terms of accepting robo-advice to make investment decisions. Only between Poland, Italy and Spain were statistically significant differences not demonstrated. Countries with a higher level of acceptance for robo-advice given for investments included Turkey, the Czech Republic, Romania and the USA. The remaining countries had a lower acceptance rate for this roboadvice feature, with Austria and Luxembourg having the lowest. Based on the $r$ strength of effect ratio, it can be stated that the strongest differences were observed between Poland, Australia and Luxembourg. All the analysis results yielded by the Mann-Whitney U tests proved statistically significant. Citizens of different nationalities differed in their willingness to let a computer analyse their expenditure. Turkey and Romania feature a higher level of acceptance than Poland of robo-advice for expenditure analysis. The inhabitants of Austria and Germany expressed the most reluctance to have a computer program give financial advice. H1 was confirmed. 


\section{ENTREPRENEURSHIP AND SUSTAINABILITY ISSUES}

ISSN 2345-0282 (online) http://jssidoi.org/jesi/

2020 Volume 8 Number 2 (December)

http://doi.org/10.9770/jesi.2020.8.2(24)

Make your research more visible, join the Twitter account of ENTREPRENEURSHIP AND SUSTAINABILITY ISSUES: @Entrepr69728810

The results of correlation analyses showed that in most countries age was associated with less acceptance for a computer program to make investment decisions. The strongest relationship in this regard was in the case of the United Kingdom, followed by the USA and Australia. Also in most countries, the willingness for a computer program to make investment decisions was proportional to the number of people in the household, with the United Kingdom featuring the strongest relationship in this regard. For all analysed countries, correlation analyses showed that age is inversely proportional to the acceptance of a computer for analysing expenses and recommending improvements. The strongest relationships in this regard were also demonstrated in the United Kingdom, followed by the USA and Australia, with Turkey having the weakest correlation. Furthermore, in most countries, the higher the number of people in the household, the greater the willingness for a computer program to analyse spending habits and recommend improvements. This relationship was also the strongest in the case of the United Kingdom and the USA. H2 was found to be true.

Also in most countries, more people in the household translated into a greater willingness for a computer program to make investment decisions, with the United Kingdom featuring the strongest correlation in this regard. Additionally, in most countries the number of people in the household was proportional to the willingness for a computer program to analyse spending habits and recommend improvements. This relationship was also found to be the strongest in the case of the United Kingdom and the USA. H2 and H3 were confirmed.

The results of correlation analyses indicated that in most countries age was associated with less acceptance for a computer program to make investment decisions. The strongest relationship in this regard was found in the United Kingdom, followed by the USA and Australia. For all analysed countries, correlation analyses showed that as age increased, acceptance for a computer to analyse expenses and recommend improvements fell. The strongest correlations in this respect were also demonstrated for the United Kingdom, followed by Australia, with Turkey having the weakest. H4 was confirmed to be accurate.

The results of the Mann-Whitney $U$ tests proved to be significant, which means the countries analysed featured differences between men and women in terms of their acceptance of robo-advice for investment. Such gender differences were not demonstrated in the case of Poland, the Czech Republic, Romania, Spain and Turkey. In all the remaining countries, men were more willing than women for a computer to make investment decisions on their behalf, with Germany and Austria having the largest gender divide. The results of the Mann-Whitney U tests were mostly irrelevant, which means that there were no differences between men and women in the analysed countries in terms of their acceptance of robo-advice for analysing expenses and recommending improvements. Such differences were only shown to apply to Germany, the Netherlands and Turkey. In the case of Germany and the Netherlands, men were more likely to have a computer analyse their expenses, while in the case of Turkey, women were more likely to do so. H5 was confirmed to be accurate.

The results of the Mann-Whitney U tests proved to be significant for the most part, meaning that the countries analysed featured differences between working and non-working people in terms of their acceptance of roboadvice for investment. Such differences were not found in the case of Poland, Austria, the Czech Republic, Luxembourg and Romania. In the remaining countries, it was demonstrated that working people were more favourably inclined towards robo-advice for investment while the largest differences were found in the United Kingdom. The results of the Mann-Whitney U tests in terms of robo-advice acceptance in the field of expenditure analysis again proved to be significant, which means that in the countries analysed there were differences between working and non-working people. Such differences were not revealed in the case of Poland, Austria, the Czech Republic and Romania. In the remaining countries, working people would be more likely to use robo-advice to 


\section{ENTREPRENEURSHIP AND SUSTAINABILITY ISSUES}

ISSN 2345-0282 (online) http://jssidoi.org/jesi/

2020 Volume 8 Number 2 (December)

http://doi.org/10.9770/jesi.2020.8.2(24)

Make your research more visible, join the Twitter account of ENTREPRENEURSHIP AND SUSTAINABILITY ISSUES: @Entrepr69728810

analyse spending and recommend improvement than non-working people. The greatest differences were also found in the United Kingdom. H6 was confirmed.

The research issues presented here are new, and the research results have practical significance and application value for entities offering automatic financial advice and household budget monitoring.

\section{References}

Anand, P. \& Sternthal, B. (1990). Ease of message processing as a moderator of repetition effect in advertising, Journal of Marketing Research, 27(3), pp. 345-353. https://doi.org/10.2307/3172591

Baker, T. \& Dellaert, B. (2017). Regulating Robo Advice Across the Financial Services Industry, University of Pennsylvania Carey Law School, Faculty Scholarship at Penn Law. 1740.

Beketov, M., Lehmann, K. \& Wittke. (2018). M. Robo Advisors: quantitative methods inside the robots. Journal of Asset Management, 19, pp. 363-370. https://doi.org/10.1057/s41260-018-0092-9

Beckett, A., Hewer, P. \& Howcroft B. (2000). An exposition of consumer behaviour in financial services industry. International Journal of Bank Marketing, 18/1, pp. 15-26. https://doi.org/10.1108/02652320010315325

Bhatia, A., Chandani, A., \& Chhateja, J. (2019). Robo advisory and its potential in addressing the behavioral biases of investors - A qualitative study in Indian context. Journal of Behavioral and Experimental Finance, 25, 100281, pp. 1-9. https://doi.org/10.1016/j.jbef.2020.100281

Bhatnagar, H. (2016). Customer Satisfaction and Technology in banking - A Scenario of Udaipur City, Arabian Journal of Business and Management Review, 6(4), pp. 1-6. https://doi.org/10.4172/2223-5833.1000228

Belanche D., Casaló L.V., \& Flavián C. (2018). Artificial Intelligence in fintech: understanding robo-advisors adoption among customers, Industrial Management \& Data System, 119, pp. 1411-1430. https://doi.org/10.1108/IMDS-08-2018-0368

Belanche, D., Casaló, L.V., Flavián, C. \& Guinalíu, M. (2019), Reciprocity and commitment in online travel communities, Industrial Management \& Data Systems, 119(2), pp. 397-411. https://doi.org/10.1108/IMDS-03-2018-0098

Blackwell, R. D., Miniard, P. W. \& Engle, J.F. (2005). Consumer behaviour. Cincinnati: South-Western College Publishing.

Boon-itt, S. (2015). Managing self-service technology services quality to enhance e-satisfaction, International Journal of Quality and Service Sciences, 7(4), pp. 373-392. https://doi.org/10.1108/IJQSS-01-2015-0013

Brian, J. Taillon, \& Bruce, A. Huhmann. (2017). Strategic consequences of self-service technology evaluations, Journal of Strategic Marketing, 27(3), pp. 268-279. https://doi.org/10.1080/0965254X.2017.1411387

Buettner R. (2017). Predicting user behaviour in electronic markets based on personality-mining in large online social network. A personality-based product recommender framework, Electronic Markets, CrossMark 27, pp. 247-264. https://doi.org/10.1007/s12525$\underline{016-0228-\mathrm{Z}}$

Collier, J. E. \& Kimes, S.E. (2012). Only If It Is Convenient: Understanding How Convenines Influences Self-Services Technology Evaluation, Journal of Services Research, 16(1), pp. 39-51. https://doi.org/10.1177/1094670512458454

Collier J. E. \& Barnes D.C. (2015). Self-services delight: Exploring the hedonic aspects of self-services, Journal of Business Research, 68, pp. 986-993. https://doi.org/10.1016/j.jbusres.2014.09.036

D’Acunto, F., Prabhala, N. \& Rossi, A. G. (2019). The Promises and Pitfalls of Robo-Advising, The Review of Financial Studies, 32(5), pp. 1983- 2020. https://doi.org/10.1093/rfs/hhz014

Das, K.K. \& Ali, S. (2020). The role of digital technologies on grown of mutual funds industry: An impact study, Research in Business \& Social Science, 9(2), pp. 171-176. https://doi.org/10.20525/ijrbs.v9i2.635

Djelassi, S., Diallo, M.F. \& Zielke, S. (2018). How self-service technology experience evaluation affect waiting time and customer satisfaction? A moderated mediation model, Decision Support Systems, Elsevier, 111, pp. 38-47. https://doi.org/10.1016/j.dss.2018.04.004

EIBIS. (2020). Who is prepared for the new digital age? Evidence from the EIB Investment Survey. Retrieved from https://www.eib.org/en/publications/who-is-prepared-for-the-new-digital-age

Erikkson K., \& Nilsson D. (2007). Determinants of the continued use of self-service technology: The case of Internet banking, Technovation, 27(4), pp. 159-167. https://doi.org/10.1016/j.technovation.2006.11.001

Gai, K. Qiu, M. \& Sun, X. (2018). A survey on fintech, Journal of Network and Computer Applications, 103, pp. $262-273$. https://doi.org/10.1016/j.jnca.2017.10.011

Gelderman, C.J., Ghijsen, P.W.Th., \& Diemen, R. (2011). Choosing self-service technologies or interpersonal services-The impact of situational factors and technology-related attitudes, Journal of Retailing and Consumer Services, 18(5), pp. 414421.https://doi.org/10.1016/j.jretconser.2011.06.003 


\section{ENTREPRENEURSHIP AND SUSTAINABILITY ISSUES}

ISSN 2345-0282 (online) http://jssidoi.org/jesi/ 2020 Volume 8 Number 2 (December)

http://doi.org/10.9770/jesi.2020.8.2(24)

Make your research more visible, join the Twitter account of ENTREPRENEURSHIP AND SUSTAINABILITY ISSUES: @Entrepr69728810

Glaser, F., Iliewa, Z., Jung, D. \& Weber, M. (2019), Towards designing robo-advisors for unexperienced investors with experience sampling of time-series data, in Davis, F., Riedl, R., vom Brocke, J., Léger, P.M. and Randolph, A. (Eds), Information Systems and Neuroscience. Lecture Notes in Information Systems and Organisation, Vol. 29, Springer, Cham, pp. 133-138.

Hung, C.S., Yen, D.C., Ouc, C.S. (2012). An empirical study of the relationship between a self-service technology investment and firm financial performance, Journal of Engineering and Technology Management, $29(1)$, pp. 62-70. https://doi.org/10.1016/j.jengtecman.2011.09.006

Iriobe, G. \& Oyinlola. (2017). The Effect of Financial Technology Services on Banks Customers Satisfaction in Nigeria, SSRN Electronic Journal. https://doi.org/10.2139/ssrn.2984215

Iberahim, H., Mohd Taufik, N.K., Mohd Adzmir, A.S. \& Saharuddin, H. (2016). Customer Satisfaction on Reliability and Responsiveness of Self Service Technology for Retail Banking Services, Procedia Economics and Finance, Elsevier, 37, pp. 13-20. https://doi.org/10.1016/S2212-5671(16)30086-7

ING International Survey - New Technologies (2019).

Jagtiani, J. \& Kose, J. (2018). Fintech: The Impact on consumers and regulatory responses. Journal of Economics and Business. 100. https://doi.org/10.1016/j.jeconbus.2018.11.002

Ji, M. (2017), Are robots good fiduciaries? Regulating robo-advisors under the investment advisers act of 1940, Columbia Law Review, 117(6), pp. 1543-1583. https://doi.org/10.2139/ssrn.3036722

Jung, D., Dorner, V., Glaser, F. \& Morana, S. (2018). Robo-Advisory - Digitalization and Automation of Financial Advisory, Business \& Information Systems Engineering, 1(60). https://doi.org/10.1007/s12599-018-0521-9

Kim, S. \& Lim, Y.J. (2010). Consumers' Perceived Importance of and Satisfaction with Internet Shopping, Electronic Markets, 11, pp. 148-154. https://doi.org/10.1080/101967801681007988

Liljander, V., Gillberg, F., Gummerus, J. \& van Rie,1 A. (2006). Technology readiness and the evaluation and adoption of self-service technologies, Journal of Retailing and Consumer Services 13, Elsevier, pp. 177-191. https://doi.org/10.1016/j.jretconser.2005.08.004

Lundahl, N., Vegholm, F. \& Silver, L. (2009). Technical and functional determinants of customer satisfaction in the bank-SME relationship. Managing Service Quality, 19(5), pp. 581-594. https://doi.org/10.1108/09604520910984382

Marinova, D., de Ruyter, K., Huang, M.H., Meuter, M.L. \& Challaballa, G. (2017). Getting smart: learning from technology empowered frontline interactions, Journal of Service Research, 20(1), pp. 29-42. https://doi.org/10.1177/1094670516679273

Mazurek, K. \& Maz, K. (2019). Human vs. Artificial Intelligence - A consumer behavioral study on advice taking among Gen Y. Master Thesis submitted to the Barcelona School of Management in Partial Fulfillment of the Requirements for the Degree of Masters of Science in Management at Universitat Pompeu Fabra. https://doi.org/10.13140/RG.2.2.11214.20807

Mordor Intelligence. (2017). Global Fintech Market (2017-2024). Retrieved from https://research.mordorintelligence.com/reports/globalfintech-market

Netscribes. (2018). Global Robo-advisory $\quad$ Market $\quad$ (2018-2023). $\quad$ Retrieved from https://www.slideshare.net/researchonglobalmarketsrogm/global-roboadvisory-market-20182023

Nitin B., Abhilas D., Aishwarya D., Lipsa D., Siddharth M., Supriyo G. (2019). Robo-Advisory: An Intestor's Perception. International Journal of Psychosocial Rehabilitation, 23(3), pp.1-11. https://doi.org/10.37200/IJPR/V23I3/PR190376

Palmiéa, M., Wincenta, J., Paridace, V., Caglard, U. (2020). The evolution of the financial technology ecosystem: An introduction and agenda for future research on disruptive innovations in ecosystems, Technological Forecasting and Social Change, $151,119779$. https://doi.org/10.1016/j.techfore.2019.119779

Parasuraman, A. (2000), Technology readiness index (Tri): a multiple-item scale to measure readiness to embrace new technologies, Journal of Service Research, 2(4), pp. 307-320. https://doi.org/10.1177/109467050024001

Rosman, C. (2018), Mad about Erica: why a million people use bank of America's chatbot, American Banker, New York, NY, available at: www.americanbanker.com/news/mad-about-erica-why-a-million-people-use-bank-of-americas-chatbot

Sabri, M.F.F. (2011). Pathways to financial success: Determinants of financial literacy and financial well-being among young adults. Iowa State University: Graduate Theses and Dissertations. 11205, pp. 54-84. http://lib.dr.iastate.edu/etd/11205

Shanmuganathan, M. (2020). Behavioural finance in an era of artificial intelligence: Longitudinal case study of robo-advisors in investment decisions, Journal of Behavioral and Experimental Finance, 100297. https://doi.org/10.1016/j.jbef.2020.100297

Sheth, J. N., Newman, B. I., \& Gross, B. L. (1991). Why we buy what we buy: A theory of consumption values. Journal of Business Research, 22(2), pp. 159-170. https://doi.org/10.1016/0148-2963(91)90050-8

Skinner, Ch. (2018). Digital Human: The fourth revolution of humanity Includes Everyone. Marshal Cavendish International: Wiley.

Statista.com. (2019). Robo-advisors worldwide report. Retrieved from: www.statista.com/outlook/337/100/robo-advisors/worldwide

Schueffel, P. (2016). Taming the Beast: A Scientific Definition of Fintech, Journal of Innovation Management, JIM 4, 4, pp. 32-54. https://doi.org/10.2139/ssrn.3097312

Świecka, B., Yeşildă̆, E., Özen, E. \& Grima, S. (2020). Financial literacy: the case of Poland. Sustainability, 12(2), 700. https://doi.org/10.3390/su12020700

Tanda, A. \& Schena, C.M. (2019). fintech, BigTech and Banks. Digitalisation and its impact on banking business models. Palgrave Macmillan. https://doi.org/10.1007/978-3-030-22426-4 


\section{ENTREPRENEURSHIP AND SUSTAINABILITY ISSUES}

ISSN 2345-0282 (online) http://jssidoi.org/jesi/

2020 Volume 8 Number 2 (December)

http://doi.org/10.9770/jesi.2020.8.2(24)

Make your research more visible, join the Twitter account of ENTREPRENEURSHIP AND SUSTAINABILITY ISSUES: @Entrepr69728810

Thorun C. \& Diels J. (2020). Consumer protection technologies: an investigation into the potentials of new digital technologies for consumer policy. Journal of Consumer Policy, 2020/43. https://doi.org/10.1007/s10603-019-09411-6

Zopounidis C., Doumpos M., Niklis D. (2018). Financial decision support: an overview of development and recent trends. EURO J Decis Process, 6, CrossMark. Springer, pp. 63-76. https://doi.org/10.1007/s40070-018-0078-3

Xie M. (2019). Development of Artificial Intelligence and Effects on Financial System, Journal of Physics. Conference Series 1187, 032084, pp. 1-7. https://doi.org/10.1088/1742-6596/1187/3/03208

Zhu Z., Nakata C., Sivakumar K. \& Grewal D. (2007). Self-services technology effectiveness: The role of design features and individual traits, Journal of the Academy of Marketing Science, 35(4), pp. 492-506. https://doi.org/10.1007/s11747-007-0019-3

\section{Acknowledgement}

The project was financed within the Regional Initiative for Excellence programme of the Minister of Science and Higher Education of Poland, years 2019-2022, grant no. 004/RID/2018/19, financing 3,000,000 PLN.

Krzysztof WALISZEWSKI is Associate Professor in Poznań University of Economics and Business, Poland, at the Institute of Finance. His research focuses on the personal financial planning and management, financial intermediation, personal financial advice, fin-tech and robo-advice.

ORCID ID: 0000-0003-4239-5875

Anna WARCHLEWSKA is Assistant Professor in Poznan University of Economics and Business, Poland, at the Institute of Finance. Her research focuses on personal financial management, modern applications of mobile banking - PFM, financial education, financial exclusion.

ORCID ID: 000-0003-0142-7877

Copyright (C) 2020 by author(s) and VsI Entrepreneurship and Sustainability Center

This work is licensed under the Creative Commons Attribution International License (CC BY).

http://creativecommons.org/licenses/by/4.0/

(c) (7) Open Access 